\title{
Clinical significance in the number of involved lymph nodes in patients that underwent surgery for pathological stage III-N2 non-small cell lung cancer
}

Takeshi Hanagiri", Masaru Takenaka, Soich Oka, Yoshiki Shigematsu, Yoshika Nagata, Hidehiko Shimokawa, Hidetaka Uramoto and Fumihiro Tanaka

\begin{abstract}
Purpose: This study investigated whether the number of involved lymph nodes is associated with the prognosis in patients that underwent surgery for pathological stage (p-stage) III/N2 NSCLC.

Subjects: This study evaluated 121 patients with p-stage III/N2 NSCLC.

Results: The histological types included 65 adenocarcinomas, 39 squamous cell carcinomas and 17 others. The average number of dissected lymph nodes was 23.8 (range: 6-55). The average number of involved lymph nodes was 5.9 (range: 1-23). The 5-year survival rate of the patients was 51.0\% for single lymph node positive, 58.9\% for 2 lymph nodes positive, 34.2\% for 3 lymph nodes positive, and 30.0\% for 4 lymph nodes positive, and 20.4\% for more than 5 lymph nodes positive. The patients with either single or 2 lymph nodes positive had a significantly more favorable prognosis than the patients with more than 5 lymph nodes positive. A multivariate analysis revealed that the number of involved lymph nodes was a significant independent prognostic factor.
\end{abstract}

Conclusion: Surgery appears to be preferable as a one arm of multimodality therapy in p-stage III/N2 patients with single or 2 involved lymph nodes. The optimal incorporation of surgery into the multimodality approach therefore requires further clinical investigation.

Keywords: non-small cell lung cancer, surgical resection, mediastial lymph node metastasis, number of involved lymph nodes, skip metastasis, postoperative prognosis

\section{Introduction}

More than 1.6 million new cases of lung cancer are diagnosed worldwide each year, causing approximately 1.3 million deaths annually and representing the highest mortality rate in comparison to any other major malignancies $[1,2]$. A surgical resection remains the mainstay for patients with early stage non-small cell carcinoma (NSCLC) [3]. However, lung cancer patients are often diagnosed with advanced disease due to the aggressiveness of this type of cancer $[4,5]$. A careful staging workup is very important to determine the optimal treatment strategy. Chemotherapy and radiotherapy is the current

\footnotetext{
* Correspondence: hanagiri@med.uoeh-u.ac.jp

Second Department of Surgery, School of Medicine, University of Occupational and Environmental Health, Kitakyushu 807, Japan
}

standard of care for patients with locally advanced (stage IIIA and stage IIIB) NSCLC. However, regardless of the total dose of radiation and the optimal chemotherapy, the outcome of stage III patients remains poor, with a median survival of 10-15 months, and 5-year survival rates of only $5-15 \%[6,7]$.

It is necessary to establish a treatment strategy to improve their prognosis of pathological stage (p-stage) III/N2 patients. Surgical intervention still plays a crucial role in selected cases, for achieving better loco-regional control and their favorable prognosis [8]. Generally, the results of surgical treatment as a multimodality therapy for pathological stage III are not satisfactory, because the 5 -year survival rates range from 20 to $30 \%[9,10]$. The range in the survival of stage III NSCLC associated with

\section{()


various prognostic factors suggests that patients at the N2 stage are a heterogeneous group [11,12]. Therefore, there is no consensus on the indications and the optimal subjects for surgical resection. This study retrospectively investigated whether the number of involved lymph nodes is associated with prognosis in patients that underwent surgery for p-stage III-N2 NSCLC. Identifying patients who receive survival benefit from surgical resection will positively contribute to determining the optimal treatment strategies.

\section{Patients and Methods}

The hospital records of 690 consecutive patients who underwent a complete resection of NSCLC between 1995 and 2005 were reviewed. There were 469 patients with N0 disease, 84 with N1 disease, and 137 patients with N2 disease. This study focused on 137 patients with p-stage III/N2 NSCLC. Ten patients that underwent preoperative chemotherapy or radiation, and 6 patients underwent segmentectomy or partial resection of the lung were excluded. The preoperative assessments included chest roentgenography and computed tomography (CT) of the chest, and upper abdomen. The clinical N2 status was defined by the presence of a lymph node more than $1 \mathrm{~cm}$ in the short axis diameter. Bone scintigraphy was performed to detect bone metastasis. MRI (magnetic resonance imaging) of the brain was routinely employed for assessment of distant metastasis. Bronchoscopy was routinely performed to obtain a pathological diagnosis by transbronchial lung biopsy, and to evaluate endobronchial staging. The patients' records, including their clinical data, preoperative examination results, details of any surgeries, histopathological findings, and the TNM stages of all patients were also reviewed.

The patients underwent lobectomy, bilobectomy or pneumonectomy were enrolled in this study. A complete mediastinal lymphadenectomy was routinely performed. After surgery, en bloc dissected tissues were separated into each lymph node precisely. All resected specimens, including the primary tumor and resected hilar and mediastinal lymph nodes, were examined to determine both the tumor histology and the extent of lymph node metastases. Intraoperative frozen sections were examined if invasion of the tumor was suspected at the surgical margins. The histopathological findings were classified according to the World Health Organization criteria, and the UICC TNM staging system (7th edition) was also employed [5,13]. We investigated the association between total number of involved lymph nodes including hilar and mediastinal lymph nodes, and survival. We also investigated the association between skip mediastinal lymph nodes metastasis and survival. Skip metastasis was defined as mediastinal lymph nodes metastasis without hilar lymph nodes metastasis.
Postoperative systemic chemotherapy was performed for patients with stage III disease if the patients could tolerate such treatment after surgery, or unless the patients refused additional chemotherapy. The chemotherapy regimen used was carboplatin + paclitaxel, or carboplatin + gemcitabine.

Follow-up information was obtained from all patients through office visits or telephone interviews either with the patient, with a relative, or with their primary physicians. The patients were evaluated every 3 months by chest roentgenography, and chest CT scans and bone scintigraphy were performed every 6 months for the first 2 years after surgery and annually thereafter. The mean duration of observation was 57 months.

The survival curve was calculated by the Kaplan-Meier method, and the data were compared using the Log-rank test for a univariate analysis. Prognostic factors were analyzed by a multivariate analysis using Cox's proportional hazard model to adjust for potential confounding factors. Categorical variables were compared by Fisher's exact test. The differences were considered to be significant, if the $p$ value was less than 0.05 . The StatView V software package (Abacus Concept, Berkeley, CA) was used for all statistical analyses.

\section{Results}

There were 121 patients who underwent either a pneumonectomy, bilobectomy or lobectomy for p-stage III/N2 NSCLC. The patients included 89 males and 32 females (Table 1). The mean age of the patients was 67.2 years (range: 44-85). One hundred patients (82.6\%) had a smoking habit. The histological types included 65 adenocarcinomas (53.7\%), 39 squamous cell carcinomas (32.2\%) and 13 large cell carcinoma (10.7\%) and 4 adenosquamous carcinomas (3.3\%). There were 27 patients in T1, 53 in T2, 32 in T3, and 9 in T4 (stage IIIB). Clinical stages were diagnosed as stage I in 46 patients, stage II in 6 , and stage III in 69. A pneumonectomy was performed in 25 (20.7\%), a bilobectomy in 9 (7.4\%), and a lobectomy in 87 (71.9\%). The average number of dissected lymph nodes (N1 and N2) was 23.8 (range: 6-55). The average number of involved lymph nodes (N1 and N2) was 5.9 (range: 1-23). Skip mediastinal lymph nodes metastasis (N1 negative) was demonstrated in 41 patients (33.8\%), and mediastinal lymph nodes metastasis with $\mathrm{N} 1$ disease (N1 positive) was found in 80 patients. The number of metastatic lymph nodes in patients with skip mediastinal lymph nodes metastasis was 1 in 17 patients, 2 in 7 patients, and $\geq 3$ in 17 patients.

The 5-year survival rate after surgery according to the pathological N stage (N0. N1. and N2) was $72.3 \%, 58.1 \%$, and $33.4 \%$, respectively (Figure 1 ). Among, the 5 -year survival rate of patients with mediastinal lymph node metastasis (N2) that had skip mediastinal lymph nodes 


\section{Table 1 Characteristics of the patients at p-stage III/N2}

\begin{tabular}{|c|c|}
\hline Average of age (range) & $67.2(44-85)$ \\
\hline Gender; male/female & $89 / 32$ \\
\hline \multicolumn{2}{|l|}{ Histology } \\
\hline Adenocarcinoma & 65 \\
\hline Squamous cell carcinoma & 39 \\
\hline Large cell carcinoma & 13 \\
\hline Adenosquamous cell carcinoma & 4 \\
\hline \multicolumn{2}{|l|}{ T factor } \\
\hline $\mathrm{T} 1$ & 27 \\
\hline $\mathrm{T} 2$ & 53 \\
\hline T3 & 32 \\
\hline T4 & 9 \\
\hline \multicolumn{2}{|l|}{ Clinical Stage } \\
\hline I & 46 \\
\hline$\|$ & 6 \\
\hline III & 69 \\
\hline \multicolumn{2}{|l|}{ Operative procedure } \\
\hline \multicolumn{2}{|l|}{ Operative procedure } \\
\hline Pneumonectomy & 25 \\
\hline Bilobectomy & 9 \\
\hline Lobectomy & 87 \\
\hline \multicolumn{2}{|c|}{ Number of involved lymph nodes (N1 +N2) } \\
\hline 1 & 17 \\
\hline 2 & 21 \\
\hline 3 & 19 \\
\hline 4 & 10 \\
\hline$\geq 5$ & 54 \\
\hline
\end{tabular}

metastasis (without N1 lymph node metastasis) was 41.7\%; however that of mediastinal lymph nodes metastasis (N2) with N1 disease was 30.1\% (Figure 2). The prognosis of patients with skip mediastinal lymph nodes metastasis showed a better tendency for survival, but there was no significant difference $(p=0.216)$. As regards the total number of involved lymph node, the 5year survival rate of the single lymph node positive patients was $51.0 \%, 58.9 \%$ for 2 lymph nodes positive, $34.2 \%$ for 3 lymph nodes positive, and $30.0 \%$ for 4 lymph nodes positive, and $20.4 \%$ for more than 5 lymph nodes positive (Figure 3 ). The patients with either single or 2 lymph nodes positive had a significantly better prognosis than the patients with more than 5 lymph nodes positive. The 5 -year survival rate in the patients with 2 or less than 2 lymph nodes positive was $55.2 \%$, whereas the 5 year survival rate in the patients with more than 2 lymph nodes positive was $24.7 \%$ ( $\mathrm{p}<0.001$; Figure 4 ). There was no significant difference between the patients with $\mathrm{N} 1$ disease and the patients with 2 or less than 2 lymph nodes metastasis.

A univariate analysis of survival in patients with stage III NSCLC showed that $\mathrm{T}$ factor ( $\mathrm{T} 1$ vs. $\mathrm{T} 2-4, \mathrm{p}=$ 0.0125 ), Surgical procedure (pneumonectomy or bilobectomy vs. lobectomy, $\mathrm{p}=0.0345)$ and number of involved lymph nodes ( $\leq 2$ vs. $3 \leq, \mathrm{p}=0.0041$ ) were significant prognostic factors (Table 2). A multivariate analysis using these significant variables ( $\mathrm{T}$ factor, surgical procedure, and number of involved lymph node) showed that the hazard ratio of the number of involved lymph node was 0.456 (95\% confidence interval $0.265-0.785$, $\mathrm{p}=0.0046)$, thus indicating that it is a significant independent prognostic factor for p-stage III/N2 NSCLC (Table 3).

\section{Discussion}

NSCLC represents one of the most common and aggressive solid tumors, and it is difficult to cure. Reducing the mortality of lung cancer is an important public health issue. The status of lymph nodes is critical in planning treatment strategies if there is no distant metastasis. A complete surgical resection is considered to be the first line treatment for individuals with stage I-II NSCLC. However, more than half of the patients with NSCLC are diagnosed with N2-3 or M1 disease [14]. While chemotherapy for patients with advanced NSCLC prolongs survival and improves their quality of life, the majority of advanced stage patients succumb to disease within 2 years, thus, there is room for improvement [15]. The Japanese Lung Cancer Registry Study of 6644 resected NSCLC cases in Japan reported the 5-year survival rate for patients with stage IIIA and IIIB were $32.8 \%$ and $30.4 \%$, respectively [10]. The 5-year survival rate for the patients with p-stage III was $33.4 \%$ in the current series, which was consistent with the Japanese Lung Cancer Registry Study. The indications for surgical treatment has remained mostly unchanged for a few decades. However, optimal therapeutic selection for stage III NSCLC is controversial. Presentations of stage III NSCLC range from apparently resectable tumors with single nodal metastasis to unresectable, bulky multi-station nodal disease, necessitating different treatment strategies. These heterogeneous subsets of stage III patients have been observed in a wide variety of clinical trials incorporating various combinations of chemotherapy, radiotherapy, and surgery. The evidence of whether surgical treatment for stage III/ $\mathrm{N} 2$ disease improves the prognosis is unclear.

Skip metastasis is defined as the presence of mediastinal lymph node metastasis (N2 disease) without intra-lobar or hilar nodal involvement (N1). The mechanism of skip metastasis is thought to be direct subpleural lymphatic spread to the mediastinum. The incidence of skip N2 metastases is $20 \%$ to $40 \%$ of all N2 diseases, but the nature and clinical significance remain unclear [16]. Some investigators report that skip metastatic disease is a favorable N2 subset, possibly because it is usually associated with single-level N2 metastatic involvement $[17,18]$. The phenomenon of skip metastasis was pathologically identified in 41 


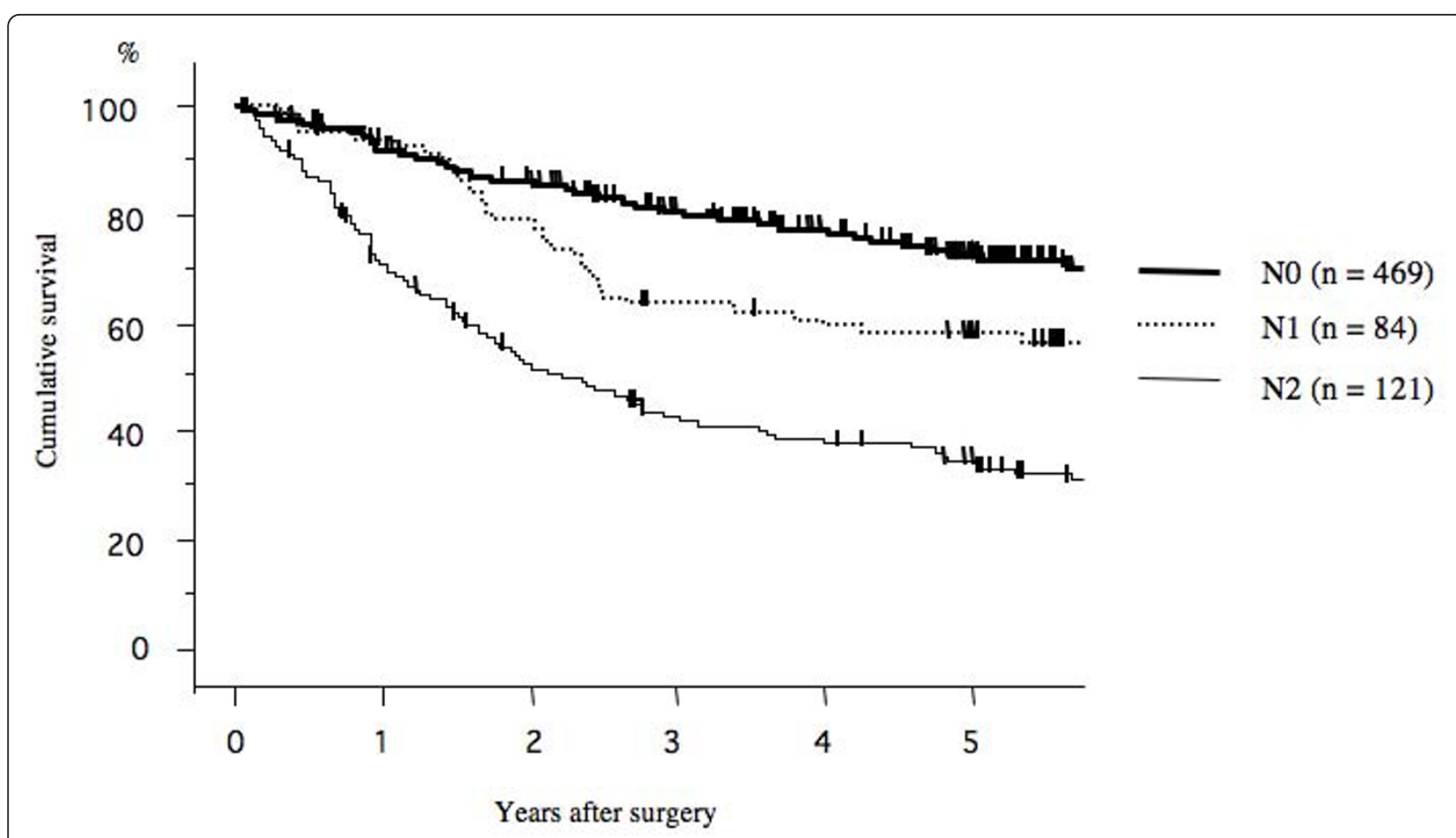

Figure 1 Overall survival curves after surgery according to the pathological $\mathbf{N}$ factor. The 5 -year survival rate after surgery according to the pathological $\mathrm{N}$ stage (NO, N1, and N2) was $72.3 \%, 58.1 \%$, and $33.4 \%$, respectively.

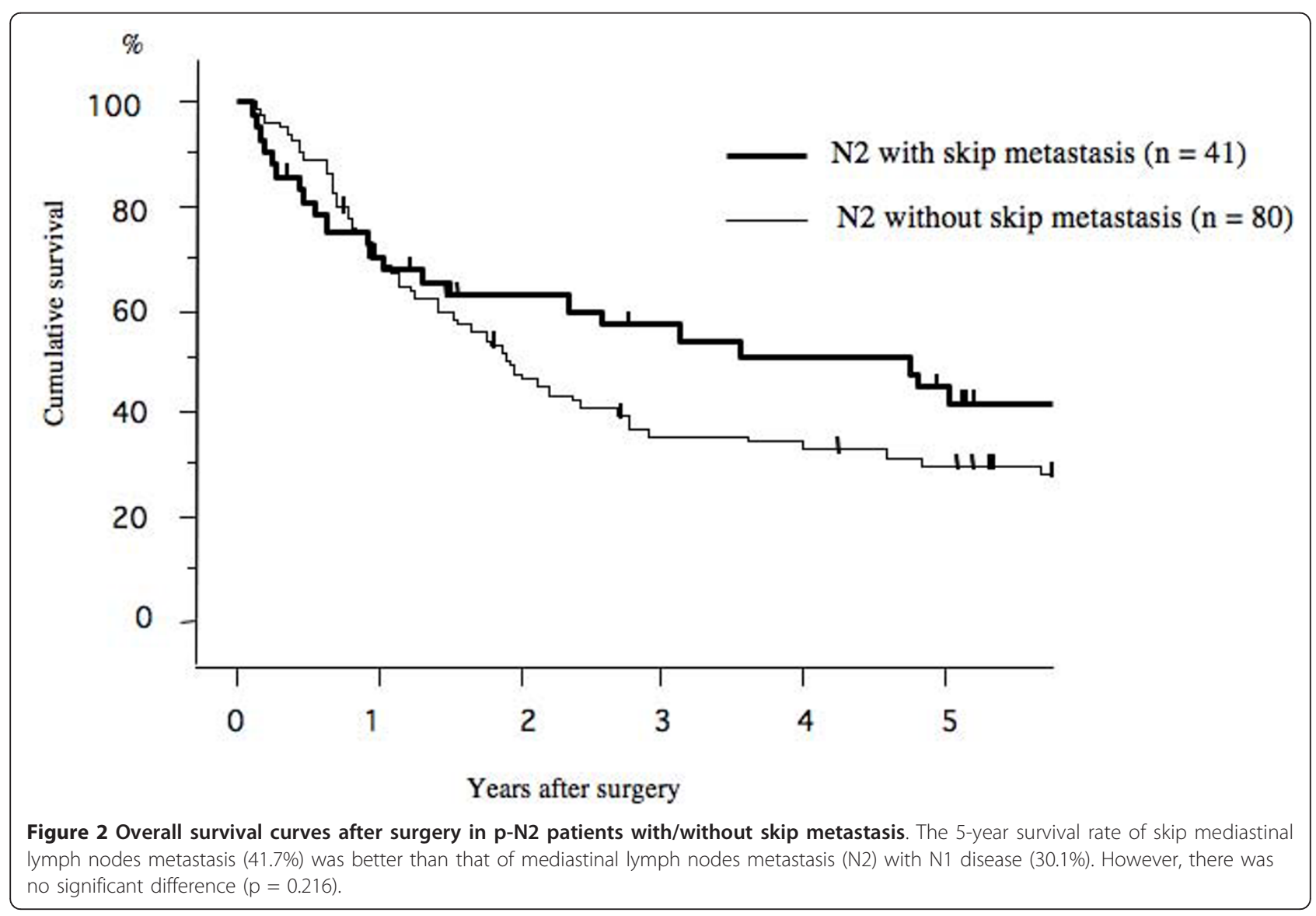



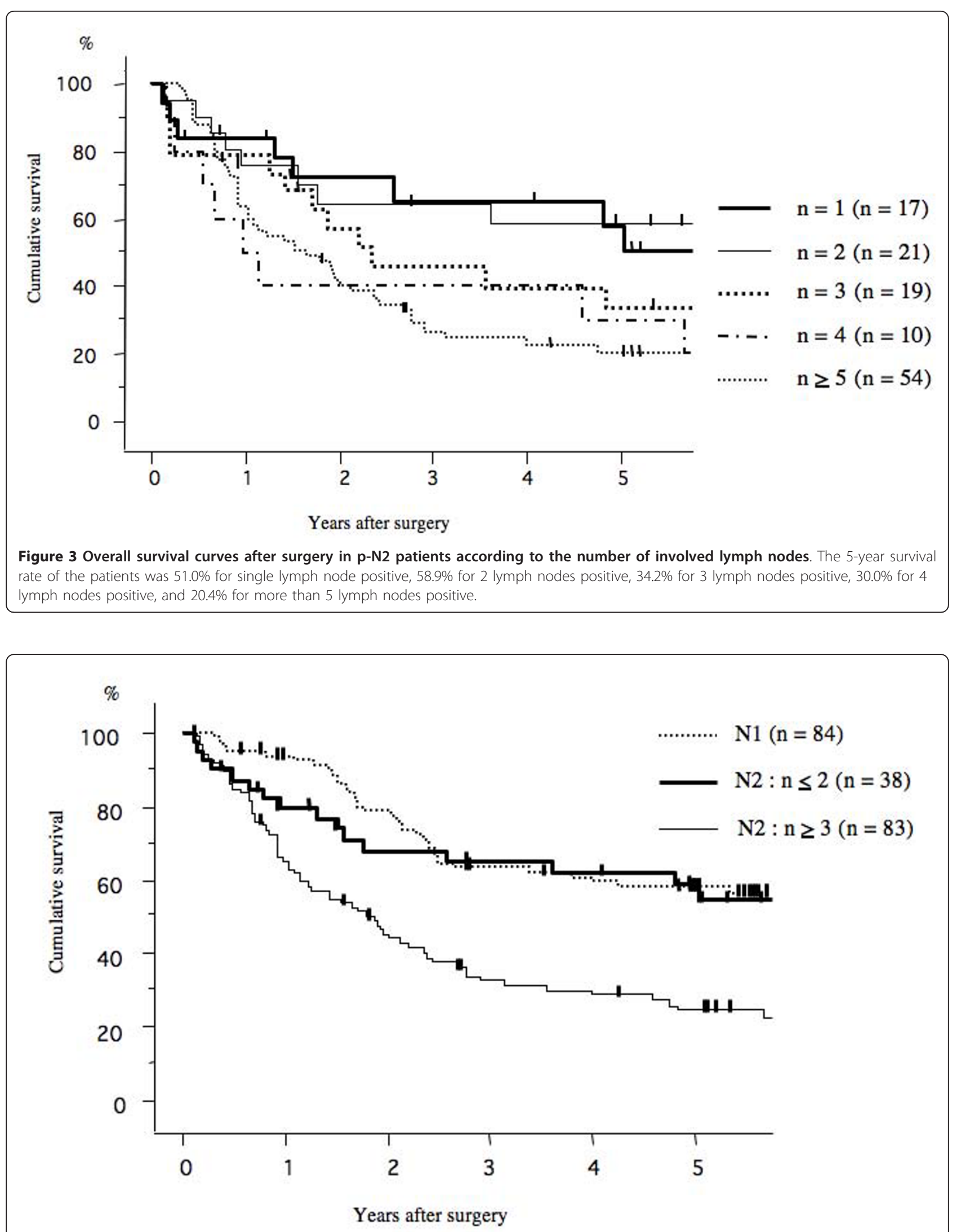

Figure 4 Comparison of the overall survival between p-N1 patients and p-N2 patients with 2 or less than 2 involved lymph nodes. There was no significant difference between the patients with N1 disease and the patients with 2 or less than 2 lymph nodes metastasis. 
Table 2 Survival of patients with p-stage III/N2 NSCLC by a univariate analysis (log-rank test)

\begin{tabular}{|c|c|c|c|}
\hline & $\mathrm{n}$ & Survival (\%) & $p$ value \\
\hline \multicolumn{4}{|l|}{ Age } \\
\hline$<75$ years & 91 & 32.0 & 0.3519 \\
\hline$\geq 75$ years & 30 & 39.5 & \\
\hline \multicolumn{4}{|l|}{ Gender } \\
\hline Male & 89 & 33.0 & 0.3981 \\
\hline Female & 32 & 40.2 & \\
\hline \multicolumn{4}{|l|}{ T factor } \\
\hline $\mathrm{T} 1$ & 27 & 47.8 & 0.0125 \\
\hline $\mathrm{T} 2-4$ & 94 & 30.8 & \\
\hline \multicolumn{4}{|l|}{ Histology } \\
\hline Adenocarcinoma & 63 & 41.0 & 0.0637 \\
\hline Others & 58 & 28.2 & \\
\hline \multicolumn{4}{|l|}{ Surgical procedure } \\
\hline Pneumonectomy/bilobectomy & 34 & 20.7 & 0.0345 \\
\hline Lobectomy & 87 & 40.1 & \\
\hline \multicolumn{4}{|l|}{ Skip metastasis } \\
\hline Yes & 41 & 41.7 & 0.2156 \\
\hline No & 80 & 30.1 & \\
\hline \multicolumn{4}{|l|}{ Number of involved lymph nodes } \\
\hline 1 or 2 & 37 & 55.2 & 0.0041 \\
\hline $3 \leq$ & 84 & 24.7 & \\
\hline
\end{tabular}

of the current patients (33.8\%). The patients with skip metastasis showed a better tendency for survival, but there was no significant survival difference between patients with skip metastasis compared to those without $(\mathrm{p}=0$. 216).

The present study focused on the number of involved lymph nodes in regional lymph node (N1 and N2). The 5years survival rates of the patients at stage III/N2 was decreased according to the total number of involved lymph node $(\mathrm{N} 1+\mathrm{N} 2)$. The patients with 2 or fewer lymph node metastases had significantly better prognosis than those with 3 or more lymph node metastasis. Previous investigators demonstrated the single N2 disease showed favorable prognosis that multiple N2 disease [12,19]. However, the present study indicated prognostic information concerning subpopulation of patients with 2 or fewer lymph node metastases. The prognosis of patients with $\mathrm{N} 2$ lymph node metastasis in 2 or fewer nodes was comparable to the results of patients with $\mathrm{N} 1$ disease. In the multivariate analysis, $\mathrm{T}$ factor and the number of involved lymph node are also significant independent prognostic factors for patients with p-stage III/N2 NSCLC.

Several investigators demonstrated the effectiveness of induction chemotherapy [20]. Most studies report that surgical resection is recommended only for patients with mediastinal downstaging after chemotherapy, and not all patients with persistent mediastinal disease will benefit from surgery [21,22]. Clinical restaging is often inaccurate and appropriate selection of patients to undergo surgical resection following induction therapy is critical [23]. Lobectomy may be safely performed following induction therapy while pneumonectomy may carry a high and possibly unacceptable rate of perioperative mortality [23,24]. Decaluwé et al. suggested that the baseline single level N2 disease is an independent prognostic factor for long-term survival in surgical multimodality treatment [25]. Stupp et al. reported that neoadjuvant chemotherapy and radiotherapy followed by surgery in selected patients with stage IIIB NSCLC was feasible, and their 5-years survival was $40 \%$, indicating it was comparable to the results of combined treatment for stage IIIA disease [26].

The present status of postoperative adjuvant chemotherapy for completely resected stage IIIA NSCLC is recommended based on the results of the large-scale phase III trials, using cisplatin-based regimens, such as IALT and ANITA studies, and a recent individual patient meta-analysis [27-29]. The clinical value of postoperative radiotherapy (PORT) in stage $\mathrm{N} 2$ non-small-cell lung cancer (NSCLC) is controversy [30]. Postoperative radiotherapy may be considered for fit patients with completely resected NSCLC with N2 nodal involvement, preferably after the completion of adjuvant chemotherapy [31]. A large multi-institutional randomized trial of PORT in these patient populations is now underway.

This retrospective study tried to clarify the prognostic importance of the number of involved lymph nodes in patients with p-stage III/N2 NSCLC who underwent complete dissection of the mediastinal lymph nodes. In conclusion, patients with 2 or fewer nodal involvement have the greater chance for cure and surgery has a significant role in their treatment. Patients with multi-station disease are frequently not amenable to complete resection and may be best approached with definitive chemotherapy and radiation. However, it is not possible to estimate exact

Table 3 Multivariate Cox proportional hazard analysis of the overall survival

\begin{tabular}{llll}
\hline Factors & relative risk & $\mathbf{9 5 \%}$ confidence interval & p value \\
\hline $\begin{array}{l}\text { T factor } \\
\text { (T1 vs T2-4) }\end{array}$ & 0.521 & $0.285-0.953$ & 0.0344 \\
$\begin{array}{l}\text { Surgical procedure } \\
\text { ((Pneumonectomy/bilobectomy vs Lobectomy) }\end{array}$ & 0.676 & $0.417-1.097$ & 0.1131 \\
$\begin{array}{l}\text { Number of involved lymph nodes } \\
\text { (I or } 2 \text { vs 3 })\end{array}$ & 0.456 & $0.265-0.785 \mathrm{~s}$ & 0.0046 \\
\hline
\end{tabular}


number of lymph nodes by using current staging technique including mediastinoscopy and endobronchial ultrasound guided transbronchial fine needle aspiration cytology. The optimal incorporation of surgery into the multimodal approach therefore requires further clinical investigations in patients with p-stage III/N2 NSCLC.

\section{Authors' contributions}

TH conceived of the study, and drafted the manuscript. MT participated in the study and performed the statistical analysis. SO, YS, YN, HS, HU, and FT participated in the study and coordination. All authors read and approved the final manuscript.

\section{Conflict of interest statement}

The authors declare that they have no competing interests.

Received: 8 August 2011 Accepted: 25 October 2011

Published: 25 October 2011

\section{References}

1. Jemal A, Siegel R, XU J, Ward E: Cancer statistics, 2010. CA Cancer J Clin 2010, 60:277-300

2. Ferlay J, Shin HR, Bray F, Forman D, Mathers C, Parkin DM: Estimates of worldwide burden of cancer in 2008: GLOBOCAN 2008. Int J Cancer 2010

3. Hanagiri T, Baba T, So T, Yasuda M, Sugaya M, Ono K, So T, Uramoto H, Takenoyama M, Yasumoto K: Time trends of surgical outcome in patients with non-small cell lung cancer. J Thorac Oncol 2010, 5:825-9.

4. Ou SH, Zell JA: Validation study of the proposed IASLC staging revisions of the T4 and $\mathrm{M}$ non-small cell lung cancer descriptors using data from 23,583 patients in the California Cancer Registry. J Thorac Oncol 2008, 3:216-27.

5. Goldstraw P, Crowley J, Chansky K, Giroux DJ, Groome PA, Rami-Porta R, Postmus PE, Rusch V, Sobin L: International Association for the Study of Lung Cancer International Staging Committee; Participating Institutions. The IASLC Lung Cancer Staging Project: proposals for the revision of the TNM stage groupings in the forthcoming (seventh) edition of the TNM Classification of malignant tumours. J Thorac Oncol 2007, 2:706-14.

6. Sause W, Kolesar P, Taylor S IV, Johnson D, Livingston R, Komaki R, Emami B, Curran W Jr, Byhardt R, Dar AR, Turrisi A: Final results of phase III trial in regionally advanced unresectable non-small cell lung cancer: Radiation Therapy Oncology Group, Eastern Cooperative Oncology Group, and Southwest Oncology Group. Chest 2000, 117:358-64

7. Okamoto I: Overview of chemoradiation clinical trials for locally advanced non-small cell lung cancer in Japan. Int J Clin Oncol 2008, 13:112-6.

8. Farray D, Mirkovic N, Albain KS: Multimodality therapy for stage III nonsmall-cell lung cancer. J Clin Oncol 2005, 23:3257-69.

9. Chansky K, Sculier JP, Crowley JJ, Giroux D, Van Meerbeeck J, Goldstraw P: International Staging Committee and Participating Institutions. The International Association for the Study of Lung Cancer Staging Project: prognostic factors and pathologic TNM stage in surgically managed non-small cell lung cancer. J Thorac Oncol 2009, 4:792-801.

10. Goya T, Asamura H, Yoshimura H, Kato H, Shimokata K, Tsuchiya R, Sohara Y, Miya T, Miyaoka E: The Japanese Joint Committee of Lung Cancer Registry. Prognosis of 6644 resected non-small cell lung cancers in Japan: a Japanese lung cancer registry study. Lung Cancer 2005, 50:227-34

11. Andre F, Grunenwald D, Pignon JP, Dujon A, Pujol JL, Brichon PY, Brouchet L, Quoix E, Westeel V, Le Chevalier T: Survival of patients with resected N2 non-small-cell lung cancer: evidence for a subclassification and implications. J Clin Oncol 2000, 18:2981-9.

12. Inoue M, Sawabata N, Takeda S, Ohta M, Ohno Y, Maeda H: Results of surgical intervention for $p$-stage IIIA (N2) non-small cell lung cancer: acceptable prognosis predicted by complete resection in patients with single N2 disease with primary tumor in the upper lobe. $J$ Thorac Cardiovasc Surg 2004, 127:1100-6.

13. Travis WD, Colby TV, Corrin B, Shimosato Y, Brambilla E, eds: Histological type of lung and pleural tumors. World Health Organization international histological classification of tumors. 3 edition. Berlin: Springer; 1999.
14. Groome PA, Bolejack V, Crowley JJ, Kennedy C, Krasnik M, Sobin LH, Goldstraw P: IASLC International Staging Committee; Cancer Research and Biostatistics; Observers to the Committee; Participating Institutions. The IASLC Lung Cancer Staging Project: validation of the proposals for revision of the $\mathrm{T}, \mathrm{N}$, and $\mathrm{M}$ descriptors and consequent stage groupings in the forthcoming (seventh) edition of the TNM classification of malignant tumours. J Thorac Oncol 2007, 2:694-705.

15. Ohe Y, Ohashi Y, Kubota K, Tamura T, Nakagawa K, Negoro S, Nishiwaki Y, Saijo N, Ariyoshi Y, Fukuoka M: Randomized phase III study of cisplatin plus irinotecan versus carboplatin plus paclitaxel, cisplatin plus gemcitabine, and cisplatin plus vinorelbine for advanced non-small-cell lung cancer: Four-Arm Cooperative Study in Japan. Ann Oncol 2007, 18:317-23.

16. Ilic N, Petricevic A, Arar D, Kotarac S, Banovic J, llic NF, Tripkovic A, Grandic L: Skip mediastinal nodal metastases in the Illa/N2 non-small cell lung cancer. J Thorac Oncol 2007, 2:1018-21.

17. Prenzel KL, Mönig SP, Sinning JM, Baldus SE, Gutschow CA, Grass G, Schneider PM, Hölscher AH: Role of skip metastasis to mediastinal lymph nodes in non-small cell lung cancer. J Surg Oncol 2003, 82:256-60.

18. Riquet M, Assouad J, Bagan P, Foucault C, Le Pimpec Barthes F, Dujon A, Danel C: Skip mediastinal lymph node metastasis and lung cancer: a particular N2 subgroup with a better prognosis. Ann Thorac Surg 2005, 79:225-33

19. Misthos P, Sepsas E, Kokotsakis J, Skottis I, Lioulias A: The significance of one-station N2 disease in the prognosis of patients with nonsmall-cell lung cancer. Ann Thorac Surg 2008, 86:1626-30.

20. Roth JA, Fossella F, Komaki R, Ryan MB, Putnam JB Jr, Lee JS, Dhingra H, De Caro L, Chasen M, McGavran M: A randomized trial comparing perioperative chemotherapy and surgery with surgery alone in resectable stage IIIA non-small-cell lung cancer. J Natl Cancer Inst 1994, 86:673-80.

21. Betticher DC, Hsu Schmitz SF, Tötsch M, Hansen E, Joss C, von Briel C, Schmid RA, Pless M, Habicht J, Roth AD, Spiliopoulos A, Stahel R, Weder W, Stupp R, Egli F, Furrer M, Honegger H, Wernli M, Cerny T, Ris HB: Mediastinal lymph node clearance after docetaxel-cisplatin neoadjuvant chemotherapy is prognostic of survival in patients with stage IIIA PN2 non-small-cell lung cancer: a multicenter phase II trial. J Clin Oncol 2003, 21:1752-1759.

22. Lorent N, De Leyn P, Lievens Y, Verbeken E, Nackaerts K, Dooms C, Van Raemdonck D, Anrys B, Vansteenkiste J, Leuven Lung Cancer Group: Longterm survival of surgically staged IIIA-N2 non-small-cell lung cancer treated with surgical combined modality approach: analysis of a 7-year prospective experience. Ann Oncol 2004, 15:1645-1653.

23. Tieu BH, Sanborn RE, Thomas CR Jr: Neoadjuvant therapy for resectable non-small cell lung cancer with mediastinal lymph node involvement. Thorac Surg Clin 2008, 18:403-15.

24. Albain KS, Swann RS, Rusch WW, Turrisi AT, Shepherd FA, Smith C, Chen Y, Livingston RB, Feins RH, Gandara DR, Fry WA, Darling G, Johnson DH, Green MR, Miller RC, Ley J, Sause WT, Cox JD: Radiotherapy plus chemotherapy with or without surgical resection for stage III non-smallcell lung cancer: a phase III randomised controlled trial. Lancet 2009, 374:379-86.

25. Decaluwé H, De Leyn P, Vansteenkiste J, Dooms C, Van Raemdonck D, Nafteux $\mathrm{P}$, Coosemans W, Lerut $\mathrm{T}$ : Surgical multimodality treatment for baseline resectable stage IIIA-N2 non-small cell lung cancer. Degree of mediastinal lymph node involvement and impact on survival. Eur $\rfloor$ Cardiothorac Surg 2009, 36:433-9.

26. Stupp R, Mayer M, Kann R, Weder W, Zouhair A, Betticher DC, Roth AD, Stahel RA, Majno SB, Peters S, Jost L, Furrer M, Thierstein S, Schmid RA, HsuSchmitz SF, Mirimanoff RO, Ris HB, Pless M: Neoadjuvant chemotherapy and radiotherapy followed by surgery in selected patients with stage IIIB non-small-cell lung cancer: a multicentre phase II trial. Lancet Oncol 2009, 10:785-93

27. Arriagada R, Bergman B, Dunant A, Le Chevalier T, Pignon JP, Vansteenkiste J: International Adjuvant Lung Cancer Trial Collaborative Group. Cisplatin-based adjuvant chemotherapy in patients with completely resected non-small-cell lung cancer. N Engl J Med 2004, 350:351-60.

28. Douillard JY, Rosell R, De Lena M, Carpagnano F, Ramlau R, GonzálesLarriba JL, Grodzki T, Pereira JR, Le Groumellec A, Lorusso V, Clary C, Torres AJ, Dahabreh J, Souquet PJ, Astudillo J, Fournel P, Artal-Cortes A, 
Jassem J, Koubkova L, His P, Riggi M, Hurteloup P: Adjuvant vinorelbine plus cisplatin versus observation in patients with completely resected stage IB-IIIA non-small-cell lung cancer (Adjuvant Navelbine International Trialist Association [ANITA]): a randomised controlled trial. Lancet Oncol 2006, 7:719-27.

29. Pignon JP, Tribodet H, Scagliotti GV, Douillard JY, Shepherd FA, Stephens RJ, Dunant A, Torri V, Rosell R, Seymour L, Spiro SG, Rolland E, Fossati R, Aubert D, Ding K, Waller D, Le Chevalier T, LACE Collaborative Group: Lung adjuvant cisplatin evaluation: a pooled analysis by the LACE Collaborative Group. J Clin Oncol 2008, 26:3552-9.

30. PORT Meta-analysis Trialists Group: Postoperative radiotherapy for nonsmall cell lung cancer. Cochrane Database Syst Rev 2005, 18:CD002142.

31. Krupitskaya Y, Loo BW Jr: Post-operative radiation therapy (PORT) in completely resected non-small-cell lung cancer. Curr Treat Options Oncol 2008, 9:343-56

doi:10.1186/1749-8090-6-144

Cite this article as: Hanagiri et al: Clinical significance in the number of involved lymph nodes in patients that underwent surgery for pathological stage III-N2 non-small cell lung cancer. Journal of Cardiothoracic Surgery 2011 6:144.

\section{Submit your next manuscript to BioMed Central} and take full advantage of:

- Convenient online submission

- Thorough peer review

- No space constraints or color figure charges

- Immediate publication on acceptance

- Inclusion in PubMed, CAS, Scopus and Google Scholar

- Research which is freely available for redistribution

Submit your manuscript at www.biomedcentral.com/submit 